Article

\title{
Insights into Bacterial Cellulose Biosynthesis from Different Carbon Sources and the Associated Biochemical Transformation Pathways in Komagataeibacter sp. W1
}

\author{
Shan-Shan Wang ${ }^{1,2,+}$, Yong-He Han ${ }^{2,3,+} \mathbb{B}^{\mathbb{D}}$, Jia-Lian Chen ${ }^{3}$, Da-Chun Zhang ${ }^{2}$, Xiao-Xia Shi ${ }^{4}$, \\ Yu-Xuan Ye ${ }^{4}$, Deng-Long Chen ${ }^{2,3,5, *}$ and Min $\mathrm{Li}^{1, *}$ \\ 1 College of Life Science, Fujian Normal University, Fuzhou 350117, China; sswang1208@163.com \\ 2 Quangang Petrochemical Research Institute, Fujian Normal University, Quanzhou 362801, China; \\ yhhan@fjnu.edu.cn (Y.-H.H.); zhdchhhu@163.com (D.-C.Z.) \\ 3 College of Environmental Science and Engineering, Fujian Normal University, Fuzhou 350007, China; \\ 18359172332@163.com \\ 4 State Key Laboratory of Pollution Control and Resource Reuse, School of the Environment, Nanjing \\ University, Nanjing 210023, China; shixx@nju.edu.cn (X.-X.S.); enproye@163.com (Y.-X.Y.) \\ 5 The Innovative Center for Eco-Friendly Polymeric Materials of Fujian Province, Quanzhou 362801, China \\ * Correspondence: dlchen@fjnu.edu.cn or chendenglong@163.com (D.-L.C.); mli@fjnu.edu.cn (M.L.); \\ Tel.: +86-0595-6817-9868 (D.-L.C.); +86-0591-2286-8205 (M.L.) \\ + These authors contributed equally to this work.
}

Received: 29 July 2018; Accepted: 27 August 2018; Published: 31 August 2018

\begin{abstract}
Cellulose is the most abundant and widely used biopolymer on earth and can be produced by both plants and micro-organisms. Among bacterial cellulose (BC)-producing bacteria, the strains in genus Komagataeibacter have attracted wide attention due to their particular ability in furthering BC production. Our previous study reported a new strain of genus Komagataeibacter from a vinegar factory. To evaluate its capacity for BC production from different carbon sources, the present study subjected the strain to media spiked with $2 \%$ acetate, ethanol, fructose, glucose, lactose, mannitol or sucrose. Then the BC productivity, BC characteristics and biochemical transformation pathways of various carbon sources were fully investigated. After 14 days of incubation, strain W1 produced $0.040-1.529 \mathrm{~g} \mathrm{~L}^{-1} \mathrm{BC}$, the highest yield being observed in fructose. Unlike BC yields, the morphology and microfibrils of $\mathrm{BC}$ s from different carbon sources were similar, with an average diameter of $35-50 \mathrm{~nm}$. X-ray diffraction analysis showed that all membranes produced from various carbon sources had 1-3 typical diffraction peaks, and the highest crystallinity (i.e., 90\%) was found for BC produced from mannitol. Similarly, several typical spectra bands obtained by Fourier transform infrared spectroscopy were similar for the BCs produced from different carbon sources, as was the $I_{\alpha}$ fraction. The genome annotation and Kyoto Encyclopedia of Genes and Genomes analysis revealed that the biochemical transformation pathways associated with the utilization of and BC production from fructose, glucose, glycerol, and mannitol were found in strain W1, but this was not the case for other carbon sources. Our data provides suggestions for further investigations of strain W1 to produce $\mathrm{BC}$ by using low molecular weight sugars and gives clues to understand how this strain produces $\mathrm{BC}$ based on metabolic pathway analysis.
\end{abstract}

Keywords: bacterial cellulose; Komagataeibacter; carbon sources; genome sequencing; metabolic pathway 


\section{Introduction}

Cellulose is the most abundant and widely used biopolymer on earth, most of which is produced by plants [1,2]. In addition to plant origin, cellulose is also naturally produced by micro-organisms including bacteria, fungi, and algae [3]. Due to its unique properties such as high purity, high crystallinity, high water-capacity, low production cost, and good biocompatibility, the cellulose produced by bacteria (i.e., bacterial cellulose, BC) has been widely used in the preparation of food hydrocolloids, high-strength recycled paper, cosmetic moisturizer, and medical materials [4-7]. By an additional modification, $\mathrm{BC}$-based materials can also be used to prepare adsorption or filter membranes for pollutant removal from aqueous solution [8,9] or to prepare electrochemical materials with high-performances [5].

In the presence of glucokinase, phosphoglucomutase and uridine triphosphate (UTP)-glucose1-phosphate uridylyltransferase, glucose is transformed to glucose-6-phosphate, glucose-1-phosphate, uridine diphosphate (UDP)-glucose, and finally to unbranched $\beta-1,4-\mathrm{D}$-glucan (i.e., $\mathrm{BC}$ ) with the aid of cellulose synthases [10,11]. Besides glucose, all substrates which can be transformed to glucose are theoretically available for BC production. For example, four strains of Komagataeibacter xylinus studied by Singhsa et al. [12] showed great ability for BC production on using fructose, lactose, maltitol, sucralose, and xylitol. Other substrates such as glycerol, sucrose, and galactose are also good carbon sources for BC production [13-15]. Unlike sugars or their derivatives, using ethanol and acetate as the substrates for BC production has been hardly reported [16]. More often, both ethanol and acetate are spiked in media to enhance BC production by improving adenosine triphosphate (ATP) production, which is responsible for energy supply in the tricarboxylic acid (TCA) cycle and sugar metabolisms. Specifically, these processes are achieved by promoting the activities of glucokinase and fructokinase for $\mathrm{BC}$ production and inhibiting the activities of gluconokinase and glucose-6-phosphate dehydrogenase in pentose phosphate metabolism for energy production [17-22].

Since the carbon sources have different molecular weights, chemical structure, and bioavailability, it can result in varied BC production rates and structural characteristics [12,23]. Among reported carbon sources, glucose is considered the main source for BC production, while fructose produces low yields of BC $[14,16]$. However, BC production abilities in different bacteria vary significantly, as do the BC properties [12,14,24-26]. Moreover, the existing studies mostly focus on the utilization of carbon sources rather than associated transformation mechanisms. Therefore, having an overview of the utilization efficiency of different carbon sources and the associated biochemical transformation pathways in a given BC-producing bacterium can provide good possibilities for optimization and improvement of $\mathrm{BC}$ production.

Our previous study reported a BC producer Komagataeibacter sp. W1, and the BC morphology, fibril distribution, purity, and functional groups were well characterized [3]. To understand how the strain synthesized BC in the presence of glucose, the draft genome sequence of W1 and the associated genes were also analyzed [3]. However, the BC synthesis using other carbon sources except for glucose is still unknown. In this work, the carbon sources, including acetate, ethanol, fructose, glycerol, lactose, mannitol, and sucrose were used to evaluate their potentials in BC production as compared to glucose. The full aims were to (1) compare BC productivity and characteristics by using different carbon sources; (2) reveal the corresponding biochemical pathways for the transformation of the above carbon sources.

\section{Materials and Methods}

\subsection{Micro-Organism, Culture Media and Cultivation}

Komagataeibacter sp. W1 used in this study was isolated from a vinegar fermentation tank in Quanzhou, China [3].

Hestrin-Schramm (HS) medium was used as the basic medium, which consisted of $2 \%$ glucose $\left(\mathrm{C}_{6} \mathrm{H}_{8} \mathrm{O}_{7} \cdot \mathrm{H}_{2} \mathrm{O}\right), 0.5 \%$ yeast extract, $0.5 \%$ peptone, $0.68 \% \mathrm{Na}_{2} \mathrm{HPO}_{4} \cdot 12 \mathrm{H}_{2} \mathrm{O}, 0.115 \% \mathrm{C}_{6} \mathrm{H}_{8} \mathrm{O}_{7} \cdot \mathrm{H}_{2} \mathrm{O}$ and $0.051 \% \mathrm{MgSO}_{4} \cdot 7 \mathrm{H}_{2} \mathrm{O}$ [27]. The medium $\mathrm{pH}$ was adjusted to 6.0 using $1.0 \mathrm{M} \mathrm{NaOH}$ or $\mathrm{HCl}$. 
Before testing the effects of carbon sources on $\mathrm{BC}$ production in strain $\mathrm{W} 1$, the bacteria were pre-cultured in basic medium at $30^{\circ} \mathrm{C}$ for $24 \mathrm{~h}$ under agitated condition $(180 \mathrm{rpm})$ and at $30{ }^{\circ} \mathrm{C}$ for 7 days under static conditions. After that, the Erlenmeyer flask was vibrated rapidly to separate the bacteria from BC membranes. The established suspension was concentrated at $8000 \mathrm{~g}$ for $5 \mathrm{~min}$ to remove the residual glucose, followed by dilution in sterile Milli-Q to a total volume of $10 \mathrm{~mL}$. Aliquots of re-suspension were transferred to a new $250 \mathrm{~mL}$ Erlenmeyer flask, which contained $100 \mathrm{~mL}$ HS medium with a final $\mathrm{OD}_{600}$ of 0.01 . To evaluate the $\mathrm{BC}$ productivities in the media spiked with different carbon sources, glucose in HS medium was replaced with acetate $\left(\mathrm{C}_{2} \mathrm{H}_{4} \mathrm{O}_{2}\right)$, ethanol $\left(\mathrm{C}_{2} \mathrm{H}_{6} \mathrm{O}\right)$, fructose $\left(\mathrm{C}_{6} \mathrm{H}_{12} \mathrm{O}_{6}\right)$, glycerol $\left(\mathrm{C}_{3} \mathrm{H}_{8} \mathrm{O}_{3}\right)$, lactose $\left(\mathrm{C}_{12} \mathrm{H}_{22} \mathrm{O}_{11}\right)$, mannitol $\left(\mathrm{C}_{6} \mathrm{H}_{14} \mathrm{O}_{6}\right)$, and sucrose $\left(\mathrm{C}_{12} \mathrm{H}_{22} \mathrm{O}_{11}\right)$, respectively. The structures of various carbon sources used in this study are given in Figure $\mathrm{S} 1$. All setups were incubated at $30^{\circ} \mathrm{C}$ for 14 days under static conditions.

\subsection{BC Purification and Yield Calculation}

The BC on the HS medium surface was collected and washed with Milli-Q water to remove medium components. To eliminate bacterial cells inside the $\mathrm{BC}$ membranes or on the $\mathrm{BC}$ surface, the samples were boiled at $100{ }^{\circ} \mathrm{C}$ for $2 \mathrm{~h}$ in a $0.1 \mathrm{M} \mathrm{NaOH}$ bath and anther $2 \mathrm{~h}$ in a Milli-Q water bath [3]. The pre-treated $\mathrm{BC}$ was soaked in Milli-Q water overnight at room temperature to remove all chemicals. After $24 \mathrm{~h}$ of storage at $-80^{\circ} \mathrm{C}$, the BC was freeze-dried (FreeZone 6 plus, Labconco, Kansas City, MI, USA) for $24 \mathrm{~h}$ [3] and then, weighed.

$\mathrm{BC}$ production was recorded as the dry weight within the volume of medium in liter $\left(\mathrm{g} \mathrm{L}^{-1}\right)$ [28]. The BC yield was calculated by Equation (1):

$$
\text { Yield }(\%)=\frac{m_{c e}}{m_{c a}} \times 100
$$

where $m_{c e}$ is dry weight of $\mathrm{BC}(\mathrm{g})$ and $m_{c a}$ is the weight of carbon source spiked in media $(\mathrm{g})$.

\subsection{BC Characterization}

Scanning electron microscopy (SEM, Quanta ${ }^{\mathrm{TM}} 250$ FEG, FEI, Hillsboro, OR, USA), X-ray diffraction (XRD, Bruker D8 ADVANCE, Karlsruhe, Germany) and Fourier transform infrared (FTIR, Thermo Scientific Nicolet iS5, Waltham, MA, USA) spectroscopy were used to characterize BC.

Before analysis, the dried BC was treated by spray-gold and observed by SEM with the spot of 3.0, high voltage of $15 \mathrm{KeV}$ and magnification of $2000 \times$. Subsequently, 100 nanofibrils of the BC were used for diameter calculation by using a Nano Measurer 1.2 (Fudan University, Shanghai, China). In this study, each $10 \mathrm{~nm}$ was set as a group and the data were presented as $\%$ of total nanofibrils. To have a full prediction of theoretical diameter distribution, the statistical histograms were plotted by using OriginPro 9.0 (OriginLab Corporation, Northampton, MA, USA).

X-ray diffraction was performed by using nickel filtered copper $K_{\mathrm{a}}$ radiation $(\lambda=0.15406 \mathrm{~nm})$ at a voltage of $40 \mathrm{kV}$ and a filament emission of $30 \mathrm{~mA}$, with $0.1^{\circ}$ step, from $4^{\circ}$ to $70^{\circ}$ ( $2 \theta$, angle). A silicon zero background plate was used to avoid any peak resulting from the sample holder. The established sample holder position and both of the holder and silicon zero background plate were used for XRD analysis [23]. The $d$-spacing between the crystal planes and an apparent crystal size (ACS) approximation were determined using Bragg's law and Scherrer's formula by Equations (2) and (3), respectively [2]:

$$
\begin{gathered}
d=\frac{\lambda}{2 \sin \theta} \\
\mathrm{ACS}=\frac{0.9 \lambda}{\mathrm{FWHM} \cos \theta}
\end{gathered}
$$

where $\lambda$ is the wavelength of the X-rays, $\theta$ is the angle between the plane and the diffracted or incident beam (i.e., Bragg's angle), and FWHM is the width of the peak at half the maximum height. FWHM was obtained by Integrated Peaks analysis based on the Peaks and Baseline module in OriginPro 9.0. 
Crystallinity index (C.I.) and percentage of crystallinity (\% crystalline) of BC were calculated by Equations (4) and (5) [29]:

$$
\begin{gathered}
\text { C.I. }=\frac{I_{m a}-I_{a m}}{I_{m a}} \\
\% \text { crystalline }=\frac{I_{m a}}{I_{m a}+I_{a m}} \times 100
\end{gathered}
$$

where $I_{m a}$ is the maximum diffraction intensity of the lattice peak between $2 \theta$ of $22^{\circ}$ to $23^{\circ}$ and $I_{a m}$ is the minimum diffraction intensity of the amorphous peak (i.e., baseline) between $2 \theta$ of $18^{\circ}$ to $19^{\circ}$.

In addition to SEM and XRD analyses, FTIR was also used to evaluate the BC characteristics based on information of the functional groups and peak annotations. Specifically, attenuated total refection (ATR) mode with 32 scans per measurement and a resolution $0.5 \mathrm{~cm}^{-1}$ in the range of $4000-400 \mathrm{~cm}^{-1}$ was carried out. Baselines for each sample spectrum were normalized and cellulose $I_{\alpha}$ content was calculated by Equation (6) [30]:

$$
\mathrm{f}_{\alpha}{ }^{\mathrm{IR}}=\frac{A_{\alpha}}{A_{\alpha}+A_{\beta}}
$$

where $A_{\alpha}$ and $A_{\beta}$ are the integrated intensities (i.e., the peak heights at 750 and $710 \mathrm{~cm}^{-1}$ ) of the contributions from celluloses $I_{\alpha}$ and $I_{\beta}$, respectively.

\subsection{Analysis of Biochemical Transformation Pathways Associated with Carbon Source Metabolisms}

To have a full insight into the mechanisms of carbon source transformation and BC biosynthesis, all associated open reading frames (orfs) based on gene prediction and Kyoto Encyclopedia of Genes and Genomes (KEGG, Kyoto, Japan) pathway annotation were summarized. The information of the draft genome sequence and functional genes for this aim were given in the Sequence Read Archive (SRA) database (National Center for Biotechnology Information, NCBI, Bethesda, MD, USA) with the accession numbers PRJNA388252 (BioProject number), SAMN07173612 (BioSample number), and SRP108180 (SRA Study number), and the supplementary data of our previous study [3]. A comprehensive analysis was conducted by incorporating the key metabolic intermediates and associated enzymes responsible for carbon sources transformation and $\mathrm{BC}$ biosynthesis in different KEGG pathways. The schematic diagram of carbon metabolisms and BC biosynthesis pathways in Komagataeibacter sp. W1 was plotted by using Microsoft PowerPoint 2016.

\subsection{Statistical Analysis}

All experiments were conducted in triplicate. The data are presented as the mean value of the triplicate with standard error. Significant differences were determined according to two-way analysis of variance (ANOVA) by Tukey's multiple comparisons test at $p \leq 0.05$ using GraphPad Prism (Release 6.0, La Jolla, CA, USA).

\section{Results and Discussions}

\subsection{BC Production from Various Carbon Sources}

$\mathrm{BC}$ production in micro-organisms is an interesting trait as this process consumes lots of energy to produce biomaterials rather than resulting in cell multiplication [31]. The possible purposes of $\mathrm{BC}$ production are to acquire oxygen, prevent ultraviolet damage, enhance antibiotic resistance, hold moisture, and maintain host-bacteria interactions [32-34]. Because glucose is the precursor for cellulose synthesis, all compounds that can be transformed to glucose are capable of BC production. Selection of the carbon substrates is one of the main requirements for efficient BC production [34]. Based on our previous study [3], the interest here in this study was to evaluate the potential of strain W1 in utilization of different carbon sources and subsequent BC production. 
After 14 days of incubation at $30^{\circ} \mathrm{C}$, the $\mathrm{BC}$ s on the surface of media containing acetate, ethanol, fructose, glucose, glycerol, lactose, mannitol and sucrose were collected and pre-treated as previously described (see details in Section 2.2). As shown in Figure 1, all eight carbon sources used in this study produced $\mathrm{BC}$; among which, fructose, glucose, glycerol and mannitol produced thick membranes, but the others produced irregular and thin membranes (Figure 1A). After freeze-drying, the membranes produced from fructose, glucose, glycerol, and mannitol had a smooth surface and good mechanical properties of typical BC, as did that of sucrose although the membrane content in this group was much lower than that in the former ones (Figure 1B). However, the dried BC membranes produced from acetate, ethanol and lactose were fragile and tough (Figure 1B), indicating that the composition and structure of the BCs might be different.

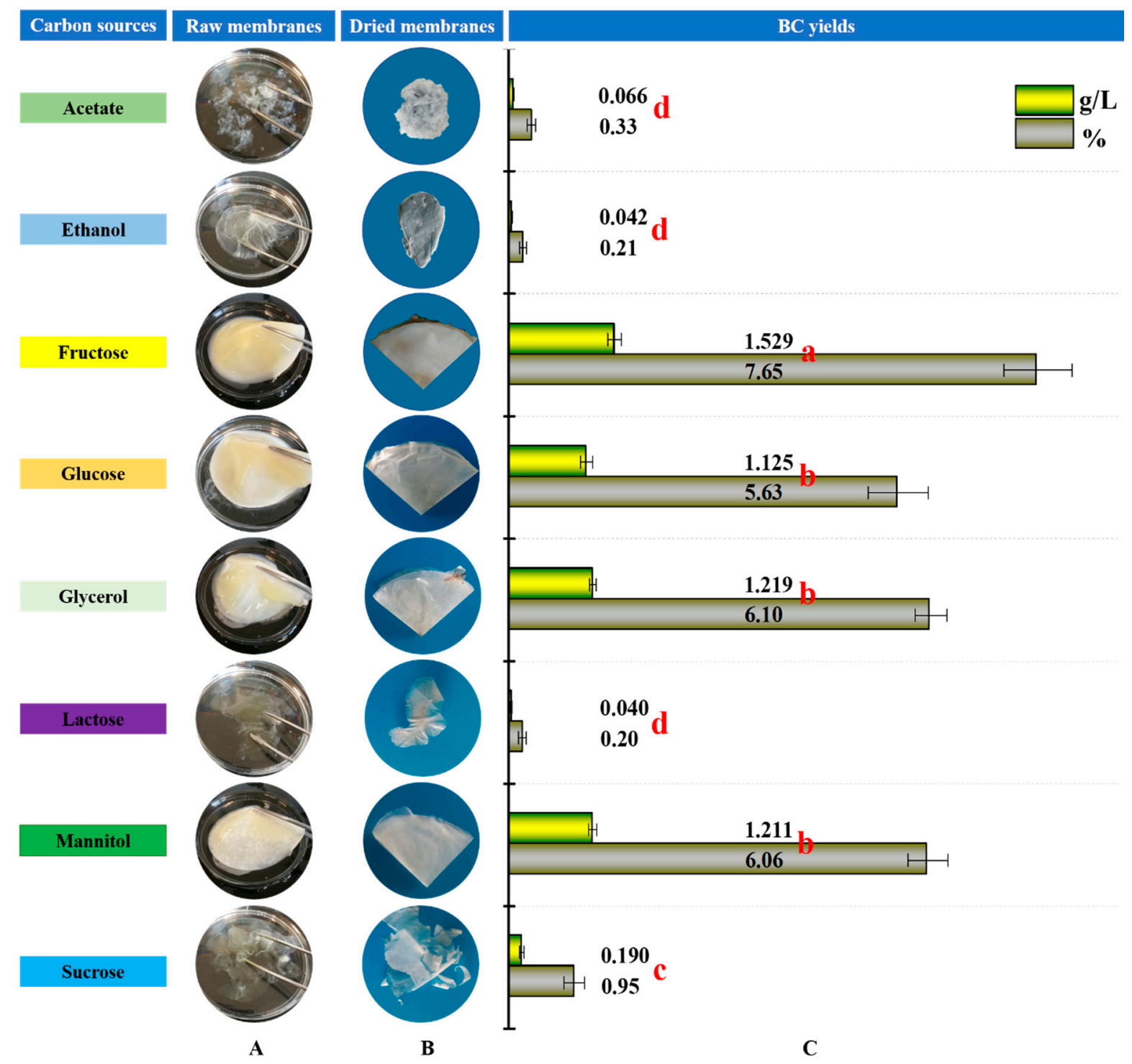

Figure 1. Bacterial cellulose (BC) production by Komagataeibacter sp. W1 grown in media spiked with different carbon sources. (A) the raw samples, (B) the samples after pre-treatment with $0.1 \mathrm{M} \mathrm{NaOH}$ for $2 \mathrm{~h}$ and freeze-dried for $24 \mathrm{~h}$ and (C) the BC yields. Different letters in red indicate no significant difference between the setups according to Limited Slip Differential (LSD) test $(p \leq 0.05)$.

To compare $\mathrm{BC}$ productivity, the $\mathrm{BC}$ s were weighed and the yields were also calculated. Similar to the findings from Figure $1 \mathrm{~A}, \mathrm{~B}$, the higher $\mathrm{BC}$ weights were observed in the groups of fructose, glucose, glycerol, and mannitol, ranging from 1.125 to $1.529 \mathrm{~g} \mathrm{~L}^{-1}$ (Figure 1C). The values were 5.9-38 fold 
of those in the media containing acetate, ethanol, lactose or sucrose $\left(\leq 0.190 \mathrm{~g} \mathrm{~L}^{-1}\right.$; Figure 1C). Correspondingly, strain W1 transformed $0.20-7.65 \%$ of carbon sources to BC (Figure 1C), of which, the content in fructose was significantly higher than that in glucose, glycerol, and mannitol $(p \leq 0.05$; Figure 1C). Similarly, apparent differences in other carbon sources were also observed (Figure 1C), suggesting that the ability of strain W1 to use different carbon sources varied significantly.

To make a comparable evaluation of BC productivity in strain $\mathrm{W} 1$, the carbon sources used for $\mathrm{BC}$ production and $\mathrm{BC}$ yields in representative bacterial strains were summarized (Table 1). Among reported carbon sources, glucose, fructose, and mannitol are best for $\mathrm{BC}$ production, which is in line with our findings (Table 1; Figure 1). In some cases, however, the BC-producing bacteria prefer to utilize sucrose, lactose or a mixture of xylose and xylulose, while other carbon sources have limited use for BC production (Table 1). One possible reason is that both the structural isomers of glucose (e.g., fructose) and the precursors of glucose (e.g., glycerol and mannitol) are easy to be transformed to glucose and enter the cycles of glucose phosphorylation, glucose-6-phosphate isomerization, UDP-glucose synthesis, and extension to form BC [35]. Unlike structural isomerization or small molecule splicing, enzymatic cleavage of disaccharides is also a good strategy to produce glucose (Figure S1), explaining why some bacteria have great efficiency in sucrose and lactose utilization for BC production [12,36]. Interestingly, strain W1 was the only producer having preference to utilize fructose among the genera Acetobacter, Gluconacetobacter, and Komagataeibacter (Table 1). In fact, this trait is often found in other genera such as Enterobacter [37] and Rhodococcus [38]. Although strain W1 did not have great capacity to utilize carbon sources for BC production $\left(0.015-0.547 \%\right.$ day $^{-1}$; Table 1$)$ as compared to other $\mathrm{BC}$ producers, its preference for fructose utilization could provide useful information for further investigations.

It is also worthy to note that the medium spiked with mannitol often produced higher BC than that with glucose $[13,39,40]$, with the highest yield of $9.58 \%$ day $^{-1}$ (Table 1). This is different from the view that glucose is considered to be the main source for BC production $[14,16]$. Additionally, for a certain strain, the BC yields under different cultivation conditions are greatly different. For example, G. xylinus PTCC 1734 has a relative yield of $0.947 \%$ day $^{-1}$ under agitated conditions, but which rose to $2.5 \%$ day $^{-1}$ under static conditions (Table 1), suggesting the significant effects of cultivation methods on $B C$ production [12]. Between above two conditions, the most suitable carbon sources for $\mathrm{BC}$ production were sucrose and mannitol, respectively (Table 1). As regards the BC yields with different strains of K. xylinus (formerly A. xylinus or G. xylinus), the data vary from $0.071 \%$ to $5.29 \%$ day $^{-1}$ (Table 1). The above mentioned observations suggest that there is no similar pattern of bacterial behavior to utilize carbon sources for $\mathrm{BC}$ production, selecting the most appropriate carbon source for $\mathrm{BC}$ production in an individual strain is very important [41].

In our study, all used carbon sources were sugars except for acetate and ethanol, which are well-known substrates responsible for enhancing ATP production and inhibiting the anti-BC production processes [17]. The studies focusing on acetate and (or) ethanol addition and their consequent effects on BC production have been well documented [17-20]. Although some studies have tried to produce $\mathrm{BC}$ using acetate or ethanol as a sole carbon source, the $\mathrm{BC}$ yields are much lower than for sugars $[16,36]$. This was supported by our study (Figure 1C; Table 1), implying that both acetate and ethanol mainly serve as BC-producing enhancers rather than transforming to BC directly. 
Table 1. The carbon sources used for bacterial cellulose (BC) production and BC productivity in representative bacterial strains.

\begin{tabular}{|c|c|c|c|c|c|}
\hline Bacteria Names & Cultivation Conditions & Carbon Sources & Concentration $(\%, w / v)$ & $\begin{array}{l}\text { Relative Yields } \\
\left(\% \text { Day }^{-1}\right)^{a}\end{array}$ & References \\
\hline Acetobacter sp. S-35 & Static, $28^{\circ} \mathrm{C}, 3$ days & $\begin{array}{l}\text { Sucrose, lactate, glucose, mannitol }{ }^{\mathrm{b}} \text {, } \\
\text { gluconate, glycerol, dulcitol, maltose, } \\
\text { lactose, sorbose, ribose, arabinose, xylose, } \\
\text { fructose, galactose }\end{array}$ & $\begin{array}{l}4 \% \text { except for dulcitol } \\
\text { and sorbose with } 2 \%\end{array}$ & up to 9.58 & Kojima et al. [40] \\
\hline $\begin{array}{l}\text { Acetobacter hansenii } \\
\text { ATCC } 10821\end{array}$ & Static, $30^{\circ} \mathrm{C}, 30$ days & $\begin{array}{c}\text { D-glucose }{ }^{\text {b }} \text {, D-xylose, D-xylulose, } \\
\text { D-xylose/D-xylulose }\end{array}$ & $2 \%$ & $0.037-1.087$ & Ishihara et al. [42] \\
\hline Acetobacter lovaniensis HBB5 & Static, $30^{\circ} \mathrm{C}, 7$ days & Glucose $^{b}$, sucrose, fructose, ethanol & $2 \%$ & $0.008-0.029$ & Çoban and Biyik [16] \\
\hline $\begin{array}{l}\text { Acetobacter pasteurianus } \\
\text { IFO } 14814\end{array}$ & Static, $30^{\circ} \mathrm{C}, 30$ days & $\begin{array}{c}\text { D-glucose }{ }^{\mathrm{b}}, \mathrm{D} \text {-xylose, D-xylulose, } \\
\text { D-xylose/D-xylulose }\end{array}$ & $2 \%$ & $0.130-0.167$ & Ishihara et al. [42] \\
\hline $\begin{array}{l}\text { Acetobacter xylinum } \\
\text { ATCC } 10245\end{array}$ & Static, $30^{\circ} \mathrm{C}, 14$ days & Glucose & $1.5 \%$ & 5.29 & Hassan et al. [39] \\
\hline Acetobacter xylinum ${ }^{\mathrm{c}}$ & $\mathrm{NM} \mathrm{d}, 35^{\circ} \mathrm{C}, 14$ days & $\begin{array}{l}\text { Sucrose }{ }^{\mathrm{b}}, \text { glucose, mannitol }{ }^{\mathrm{b}} \text {, sorbitol, } \\
\text { galactose, lactose, acetic acid, maltose }^{\text {a }}\end{array}$ & $5-7 \%$ & $\geq 0.057^{\mathrm{e}}$ & Ramana et al. [36] \\
\hline Acetobacter xylinus IFO 15606 & Static, $30^{\circ} \mathrm{C}, 30$ days & $\begin{array}{l}\text { D-glucose, D-xylose, D-xylulose, } \\
\text { D-xylose/D-xylulose }{ }^{\text {b }}\end{array}$ & $2 \%$ & $0.147-0.347$ & Ishihara et al. [42] \\
\hline $\begin{array}{l}\text { Chromobacterium violaceum } \\
\text { ATCC } 12472\end{array}$ & Static, $32{ }^{\circ} \mathrm{C}, 3$ days & Glucose & $2 \%$ & NM & Recouvreux et al. [43] \\
\hline Enterobacter amnigenus GH-1 & Static, $30^{\circ} \mathrm{C}, 14$ days & $\begin{array}{l}\text { D-Glucose, D-fructose }{ }^{\text {b }} \text {, lactose, mannitol, } \\
\text { inositol, sucrose, maltose, glycerol }\end{array}$ & $2 \%$ & 1.0 & Hungund and Gupta [44] \\
\hline Enterobacter sp. & Agitated, $30^{\circ} \mathrm{C}, 24$ days & Glucose & $2 \%$ & 0.5 & Ago et al. [37] \\
\hline $\begin{array}{l}\text { Gluconacetobacter intermedius } \\
\text { NEDO-01 }\end{array}$ & $\begin{array}{l}\text { Static, } 30^{\circ} \mathrm{C}, 3 \text { days } \\
\text { Agitated, } 30^{\circ} \mathrm{C}, 4 \text { days }\end{array}$ & Glycerol & $2 \%$ & $\begin{array}{l}\text { NM } \\
4.25\end{array}$ & Kose et al. [15] \\
\hline Gluconacetobacter sacchari & Static, $30^{\circ} \mathrm{C}, 4$ days & Glucose & $2 \%$ & 3.375 & Trovatti et al. [45] \\
\hline $\begin{array}{l}\text { Gluconacetobacter xylinus } \\
\text { ATCC } 53524\end{array}$ & Static, $30^{\circ} \mathrm{C}, 2$ or 4 days & $\begin{array}{l}\text { Mannitol }{ }^{\mathrm{b}} \text {, glucose, glycerol, fructose, } \\
\text { sucrose }^{\mathrm{b}} \text {, galactose }\end{array}$ & $2 \%$ & 5.10 or 4.79 & Mikkelsen et al. [13] \\
\hline $\begin{array}{l}\text { Gluconacetobacter xylinus } \\
\text { CH001 }\end{array}$ & Static, $28^{\circ} \mathrm{C}, 14$ days & Xylose & $1-3 \%$ & up to 0.482 & Yang et al. [19] \\
\hline $\begin{array}{l}\text { Gluconacetobacter xylinus } \\
\text { PTCC } 1734\end{array}$ & Agitated, $28^{\circ} \mathrm{C}, 7$ days & Mannitol, sucrose ${ }^{b}$, glucose & $2-5 \%$ & $\sim 0.947$ & Mohammadkazemi et al. [28] \\
\hline $\begin{array}{l}\text { Gluconacetobacter xylinus } \\
\text { PTCC } 1734\end{array}$ & Static, $28^{\circ} \mathrm{C}, 20$ days & $\begin{array}{l}\text { Glucose, fructose, mannitol }{ }^{\mathrm{b}}, \\
\text { sucrose, glycerol }\end{array}$ & $2 \%$ & up to 2.5 & Tabaii and Emtiazi [41] \\
\hline
\end{tabular}


Table 1. Cont.

\begin{tabular}{|c|c|c|c|c|c|}
\hline Bacteria Names & Cultivation Conditions & Carbon Sources & Concentration $(\%, w / v)$ & $\begin{array}{l}\text { Relative Yields } \\
\left(\% \text { Day }^{-1}\right)^{a}\end{array}$ & References \\
\hline Komagataeibacter medellinensis & Static, $28^{\circ} \mathrm{C}, 8$ days & Fructose, glucose ${ }^{b}$, sucrose & $2 \%$ & $0.238-1.75$ & Molina-Ramírez et al. [2] \\
\hline Komagataeibacter rhaeticus PG2 & Static, $28^{\circ} \mathrm{C}, 15$ days & $\begin{array}{l}\text { Fructose, lactose, xylose, sucrose, } \\
\text { galactose, mannitol, sorbitol, and glycerol }\end{array}$ & $2 \%$ & up to 2.3 & Thorat and Dastager [46] \\
\hline $\begin{array}{l}\text { Komagataeibacter } \\
\text { saccharivorans PE } 5\end{array}$ & Static, $30^{\circ} \mathrm{C}, 14$ days & Mannitol & $1.5 \%$ & 6.00 & Hassan et al. [39] \\
\hline $\begin{array}{l}\text { Komagataeibacter xylinus KX, } \\
\text { TISTR 086, } 428,975 \text { and } 1011\end{array}$ & $\begin{array}{l}\text { Static, } 30^{\circ} \mathrm{C}, 7 \text { days } \\
\text { Agitated, } 30^{\circ} \mathrm{C}, 7 \text { days }\end{array}$ & $\begin{array}{l}\text { Glucose }^{\mathrm{b}} \text {, fructose, lactose }{ }^{\mathrm{b}} \text {, maltitol, } \\
\text { sucralose, xylitol }\end{array}$ & $5 \%$ & $\begin{array}{l}0.326-0.526 \\
\text { up to } 1.34\end{array}$ & Singhsa et al. [12] \\
\hline $\begin{array}{c}\text { Komagataeibacter xylinus } \\
\text { B-12068 }\end{array}$ & Static, $30^{\circ} \mathrm{C}, 7$ days & $\begin{array}{c}\text { Glucose }{ }^{\mathrm{b}} \text {, sucrose, galactose, } \\
\text { maltose, mannitol }\end{array}$ & $2 \%$ & $0.071-1.571$ & Volova et al. [47] \\
\hline Rhodococcus sp. MI 2 & Static, $25^{\circ} \mathrm{C}, 14$ days & $\begin{array}{l}\text { Glucose, fructose }{ }^{b} \text {, sucrose, lactose, } \\
\text { sorbitol, and mannitol }\end{array}$ & $2 \%$ & $\sim 2.25$ & Tanskul et al. [38] \\
\hline $\begin{array}{l}\text { Saccharomyces cerevisiae } \\
\text { CGMCC1670 }\end{array}$ & Static, $30^{\circ} \mathrm{C}, 22$ days & Glucose & $5 \%$ & $\sim 0.118$ & Tan et al. [48] \\
\hline Komagataeibacter sp. W1 & Static, $30^{\circ} \mathrm{C}, 14$ days & $\begin{array}{l}\text { Acetate, ethanol, fructose, glucose, } \\
\text { glycerol, lactose, mannitol }{ }^{\text {b }} \text {, sucrose }\end{array}$ & $2 \%{ }^{f}$ & $0.015-0.547$ & This study \\
\hline
\end{tabular}

${ }^{\mathrm{a}}$ Since the amount of carbon sources used for $\mathrm{BC}$ production was different, the $\mathrm{BC}$ productivity was calculated based on the initial and final contents of carbon sources and $\mathrm{BC}$ within the incubation time. ${ }^{b}$ Carbon source for the highest BC production. ${ }^{c}$ The bacteria have been re-classified into the genus Komagataeibacter. ${ }^{d}$ Not mentioned. ${ }^{e}$ Both sucrose and mannitol $\left(60-70 \mathrm{~g} \mathrm{~L}^{-1}\right)$ produced similar amounts of BC with the addition of peptone or casein hydrolysate. ${ }^{\mathrm{f}}$ All carbon sources were normalized to glucose based on $\mathrm{C}$ element amount. 


\subsection{BC Morphology and Microfibril Analysis by SEM Observation}

The morphology and structural characteristics of BC membranes produced by Komagataeibacter sp. W1 from various carbon sources were evaluated by SEM. As can be seen in Figure 2A-H, all carbon sources used in this study produced BC pellicles with a dense morphology. Our findings were similar to K. xylinus strains KX, TISTR 086, 428, 975, 1011, and B-12068 [12,47] but different from K. medellinensis and K. xylinus CH001 [2,19], the latter two produced a less dense network of microfibrils with high porosity of up to $60 \%$. This indicates that different bacteria or bacterial strains may have a different interwoven pattern to produce BC.
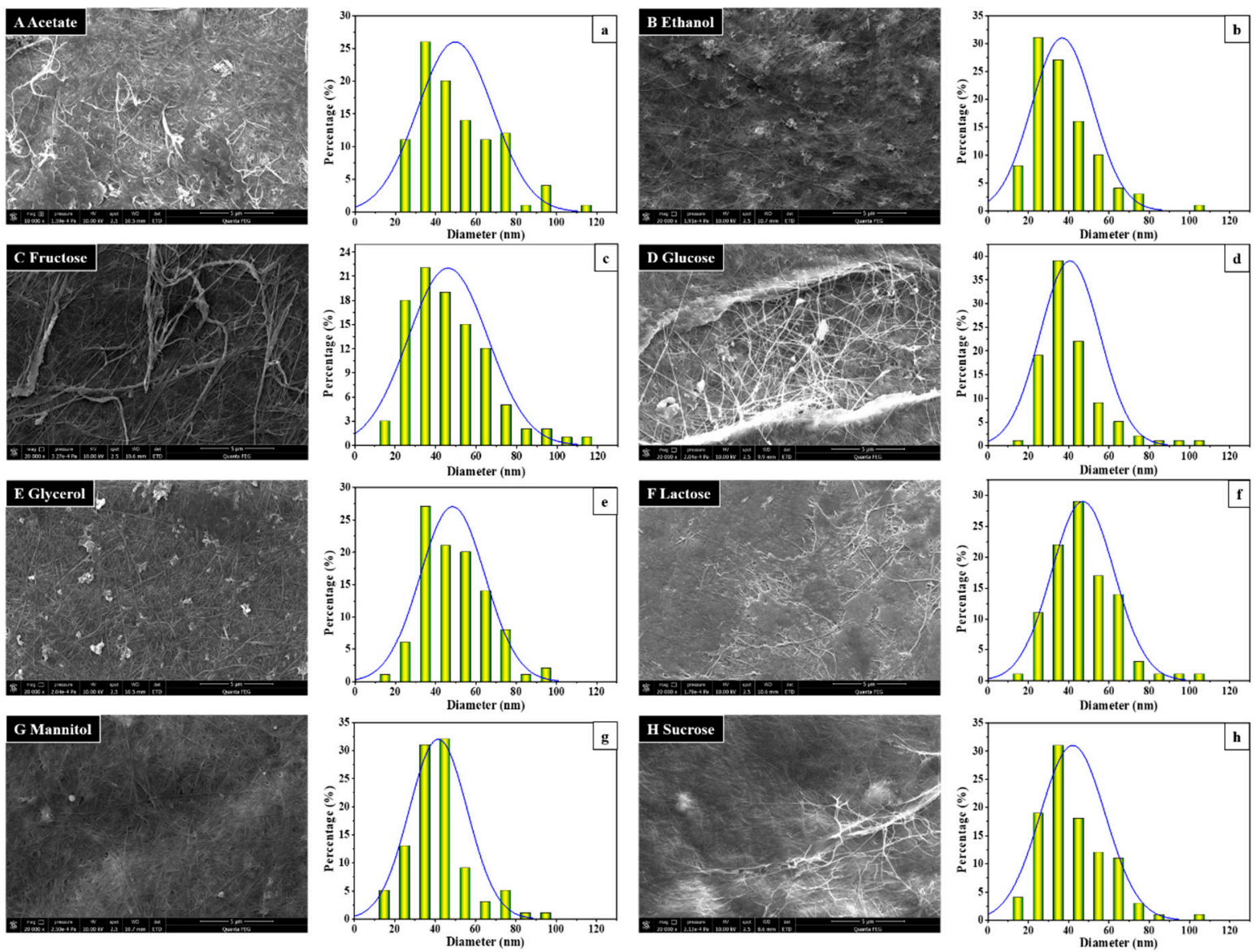

Figure 2. Morphology (A-H) and diameter distribution ( $\mathbf{a}-\mathbf{h})$ of the BC produced by Komagataeibacter sp. W1 grown in the media spiked with different carbon sources. While the BC morphology was observed with scanning electron microscopy (SEM) with a spot of 3.0, high voltage of $15 \mathrm{KeV}$, and magnification of 20,000 $\times$, the diameter calculation was performed on Nano Measurer 1.2 by calculating 100 nanofibrils randomly on the SEM images.

Due to the indistinguishable differences in $\mathrm{BC}$ morphology, we also calculated the $\mathrm{BC}$ diameter distribution by Nano Measurer 1.2 based on SEM images. The results showed that all carbon sources could produce $30 \mathrm{~nm}$ or smaller microfibrils, with an average diameter of 40-50 nm except for ethanol (Figure 2a-h). Our data were in line with the study from Volova et al. [47], suggesting that the small microfibrils were also likely to be associated with a lower density of $\mathrm{BC}$ as described previously. It was apparent that the visible component of $B C$ in our study was cellulose ribbons (often 40-60 nm) rather than nanofibrils because the diameter of the sub-elementary fibrils is $3-4 \mathrm{~nm}[49,50]$. Although the appearances of BCs produced from acetate, ethanol, lactose, and sucrose were different from other substrates (Figure 1), both SEM imaging and diameter distribution analysis verified that all carbon 
sources used in this study produced typical BC (Figure 2). However, the reasons influencing BC production efficiency in Komagataeibacter sp. W1 still warrant future investigations.

\subsection{Crystalline Differences of BC Membranes Produced from Various Carbon Sources}

It is well-known that BC is a homogeneous polycrystalline macromolecular compound composed of ordered crystalline and less ordered amorphous regions [51]. To determine the crystal structure and the crystalline contents of BC, all samples were analyzed by XRD. Figure 3 shows that different carbon sources result in different diffraction profiles. Specifically, the BCs produced from fructose, glucose, glycerol, and mannitol displayed two typical peaks at $2 \theta$ of $14.5^{\circ}$ and $22.7^{\circ}$ with strong intensity and a weak peak at $2 \theta$ of $16.6^{\circ}$ (Figure $3 c-e, g$ ). While the two broad peaks were assigned to (100) and (110) planes of cellulose $I_{\alpha}$ or $(1 \overline{1} 0)$ and (200) planes of cellulose $I_{\beta}$, respectively, the weak peak indicated the presence of the (010) plane of cellulose $I_{\alpha}$ or the (110) plane of cellulose $I_{\beta}$ (Figure 3) [52]. The higher intensity of the peak $14.5^{\circ}$ than that of the peak $16.6^{\circ}$ made it clear that the content of $I_{\alpha}$ was higher than $I_{\beta}$ [53] and the shape of the cellulose crystallites was rectangular rather than square cross-sectional [51], in agreement with the cases of Singhsa et al. [12] and Keshk and Sameshima [54]. It was interesting to note that although acetate and ethanol produced limited BCs, they showed a similar XRD pattern to the $\mathrm{BCs}$ produced from the above-mentioned sugars (Figure $3 \mathrm{a}, \mathrm{b}$ ). However, only one weak peak was observed on BC membranes produced from lactose and sucrose (Figure 3f,h). At around $2 \theta$ of $28.6^{\circ}$, a weak peak was found in the acetate and glycerol groups, which has been scarcely reported and needs further investigations (Figure $3 \mathrm{a}, \mathrm{e}$ ). Our data indicated that all carbon sources could produce $\mathrm{BC}$ with high crystallinity except for lactose and sucrose.

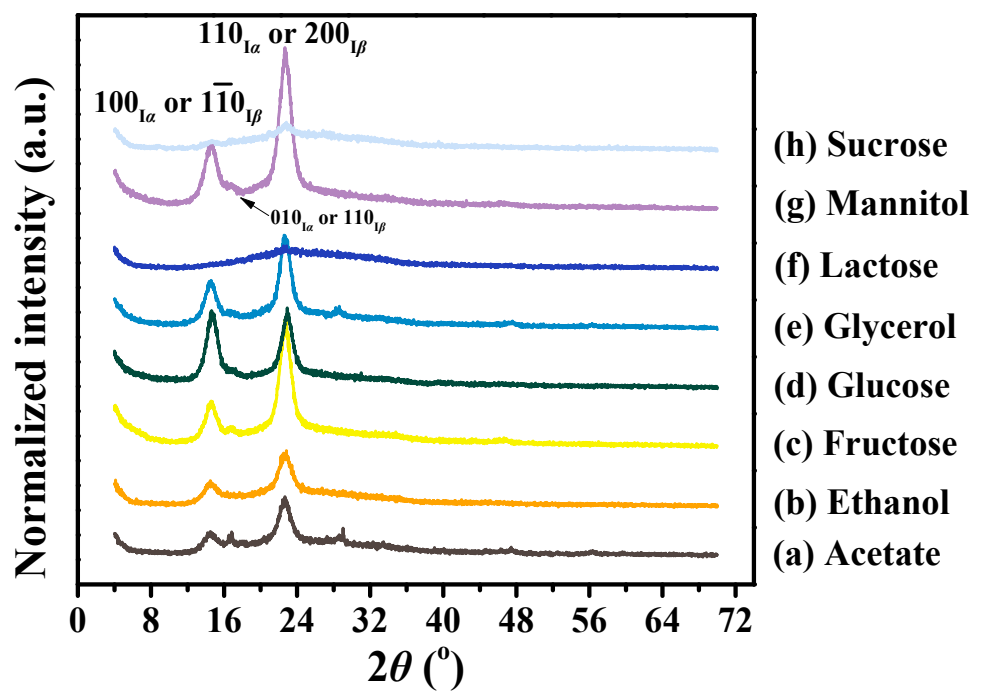

Figure 3. Comparative X-ray diffraction (XRD) analysis of the BC produced by Komagataeibacter sp. W1 grown in the media spiked with various carbon sources. The XRD pattern was obtained using nickel filtered copper $K_{\alpha}$ radiation, with $0.1^{\circ}$ steps, from $4^{\circ}$ to $70^{\circ}(2 \theta)$.

As shown in Table 2, the interplanar crystal distance (i.e., $d$-spacing) of each peak of most of the $\mathrm{BC}$ s was the same, assuming that peak shifts at $2 \theta$ of $14.5^{\circ}$ did not occur and different $\mathrm{BC}$ s had the same contents of cellulose $I_{\alpha}$ [23]. Due to the absence of the $\left(100_{I \alpha}\right)$ or $\left(1 \overline{1}_{I}\right)$ peak in the lactose group and the $\left(010_{I \alpha}\right)$ or $\left(110_{I \beta}\right)$ peak in ethanol, lactose and sucrose groups, all the corresponding $d$-spacing and ACSs were not available (Table 2). Unlike $d$-spacing, however, the ACS varied significantly in different groups (Table 2). For instance, the ACSs of peak 1 in fructose, glucose, glycerol, and mannitol were similar, at 7.9-8.8 nm, which reduced to $6.7-6.9 \mathrm{~nm}$ in acetate and ethanol and increased to $23.6 \mathrm{~nm}$ in sucrose (Table 2). The lower or higher ACSs in acetate, ethanol, lactose, and sucrose might be attributed to the irregular textile structures of BC microfibrils (Figures 1 and 2). Similar to peak 1 , 
most BCs had a typical ACS in peak 3, but the ACSs in lactose and sucrose were much lower than that in the others (Table 2). However, since peak 2 was weak, the corresponding ACSs did not follow similar trends as for peak 1 and peak 3 (Figure 3; Table 2), which again verified the high contents of $I_{\alpha}$ in all groups as previously described.

Table 2. D-spacing, apparent crystal size (ACS), crystallinity index (C.I.). and \% crystalline of BC samples produced from different carbon sources.

\begin{tabular}{|c|c|c|c|c|c|c|c|c|c|c|}
\hline \multirow{2}{*}{ Carbon Sources } & \multicolumn{2}{|c|}{$\begin{array}{c}\text { Peak } 1 \\
\left(100_{I \alpha} \text { or } 1 \overline{1} 0_{I \beta}\right)\end{array}$} & \multicolumn{2}{|c|}{$\begin{array}{c}\text { Peak } 2 \\
\left(010_{I \alpha} \text { or } 110_{I \beta}\right)\end{array}$} & \multicolumn{2}{|c|}{$\begin{array}{c}\text { Peak } 3 \\
\left(110_{I \alpha} \text { or } 200_{I \beta}\right)\end{array}$} & \multicolumn{2}{|c|}{ At $2 \theta$ Scale } & \multirow[t]{2}{*}{ C.I. } & \multirow[t]{2}{*}{$\begin{array}{c}\% \\
\text { Crystalline }\end{array}$} \\
\hline & $\begin{array}{l}d \text {-Spacing } \\
\text { (nm) }\end{array}$ & $\begin{array}{l}\text { ACS } \\
(\mathrm{nm})\end{array}$ & $\begin{array}{l}d \text {-Spacing } \\
(\mathrm{nm})\end{array}$ & $\begin{array}{l}\text { ACS } \\
(\mathrm{nm})\end{array}$ & $\begin{array}{l}d \text {-Spacing } \\
(\mathrm{nm})\end{array}$ & $\begin{array}{l}\text { ACS } \\
(\mathrm{nm})\end{array}$ & $I_{a m}$ & $I_{m a}$ & & \\
\hline Acetate & 0.60 & 6.7 & 0.53 & 15.5 & 0.39 & 7.8 & 133 & 636 & 0.79 & 83 \\
\hline Ethanol & 0.60 & 6.9 & $-{ }^{a}$ & - & 0.39 & 7.2 & 126 & 602 & 0.79 & 83 \\
\hline Fructose & 0.60 & 8.2 & 0.53 & 9.4 & 0.39 & 8.9 & 165 & 1323 & 0.88 & 89 \\
\hline Glucose & 0.60 & 8.8 & 0.53 & 6.8 & 0.39 & 9.2 & 132 & 844 & 0.84 & 86 \\
\hline Glycerol & 0.60 & 8.6 & 0.53 & 10.7 & 0.39 & 8.9 & 140 & 978 & 0.86 & 87 \\
\hline Lactose & - & - & - & - & 0.39 & 1.8 & 99 & 273 & 0.64 & 73 \\
\hline Mannitol & 0.60 & 7.9 & 0.53 & 8.0 & 0.39 & 8.8 & 185 & 1674 & 0.89 & 90 \\
\hline Sucrose & 0.60 & 23.6 & - & - & 0.39 & 4.6 & 112 & 322 & 0.65 & 74 \\
\hline
\end{tabular}

a Since the peak was weak, both the $d$-spacing and ACS were not available.

Besides $d$-spacing and ACS, we also determined C.I. and \% crystalline of BC samples produced from different carbon sources. In general, the C.I. ranged from $0.64-0.89$, the highest and the lowest being in mannitol and lactose, respectively (Table 2). Correspondingly, all BCs had a high crystallinity ranging from $83-90 \%$ except for $73 \%$ for lactose and $74 \%$ for sucrose, respectively (Table 2). This followed similar trends as for $d$-spacing and ACS (Table 2) but was different from BC yields (Figure 1). Moreover, our data showed a similar crystallinity to that reported by previous studies $[2,14,23]$. In most cases, a lower ACS corresponded to a higher BC crystallinity (Table 2), which was supported by a recent study from Meza-Contreras et al. [55]. Because the peak corresponding to the (200) lattice plane often shows the highest intensity in the diffraction patterns of native BC (Figure 3) and plays an important role in higher crystallinity and smaller crystallite size [19], mannitol could be an ideal carbon source for BC production in Komagataeibacter sp. W1.

\subsection{Functional Groups and Cellulose Types Characterization Based on FTIR Analysis}

The FTIR spectra of BCs prepared from different carbon sources are shown in Figure 4. Although different carbon sources resulted in great differences in BC yields (Figure 1C), and XRD patterns of BCs also varied significantly (Figure 3), all FTIR spectra exhibited several typical vibration bands with little difference (Figure 4), implying the same chemical structure for the different BCs prepared from various carbon sources [2]. Of the 22 peaks, most have been assigned to certain functional groups in previous studies. For example, several typical adsorptions associated with $\mathrm{O}-\mathrm{H}$ stretching at around $3345 \mathrm{~cm}^{-1}, \mathrm{C}-\mathrm{H}$ stretching at around $2900 \mathrm{~cm}^{-1}, \mathrm{C}-\mathrm{O}-\mathrm{H}$ antisymmetric bridge stretching of $1,4-\beta$-glucoside at around $1160 \mathrm{~cm}^{-1}$ and antisymmetric out-of-phase ring stretching of $\beta$-glucosidic linkages between glucose units at around $900 \mathrm{~cm}^{-1}$ were observed (Figure 4; Table 3). Similarly, we also found other adsorptions due to $\mathrm{O}-\mathrm{H}$ bending at around 1360, 1280, and $1205 \mathrm{~cm}^{-1}, \mathrm{O}-\mathrm{H}$ in-plane bending at around 1430 and $1335 \mathrm{~cm}^{-1}, \mathrm{C}-\mathrm{O}$ bending at around 1108 , 1055 , and $1031 \mathrm{~cm}^{-1}$, and O-H out-of-phase bending at the wavenumbers below $660 \mathrm{~cm}^{-1}$ (Figure 4; Table 3). However, the adsorptions at 1430, 1335, 1108, 1055, and $1031 \mathrm{~cm}^{-1}$ might also be assigned to $\mathrm{CH}_{2}$ symmetric bending, $\mathrm{C}-\mathrm{H}$ deformation, $\mathrm{C}-\mathrm{C}$ bonds of the monomer units of polysaccharide, and $\mathrm{C}-\mathrm{O}-\mathrm{C}$ pyranose ring skeletal vibration, respectively (Table 3). Our study revealed that the BCs produced by Komagataeibacter sp. W1 were mostly composed of cellulose I (adsorptions at around 3345, 1430, 1160, and $900 \mathrm{~cm}^{-1}$ ) with few cellulose II (adsorption at around 1335, 1315, and $1280 \mathrm{~cm}^{-1}$ and a blue-shift of wavenumber from 1430 to around $1425 \mathrm{~cm}^{-1}$ ) (Table 3) [3]. 


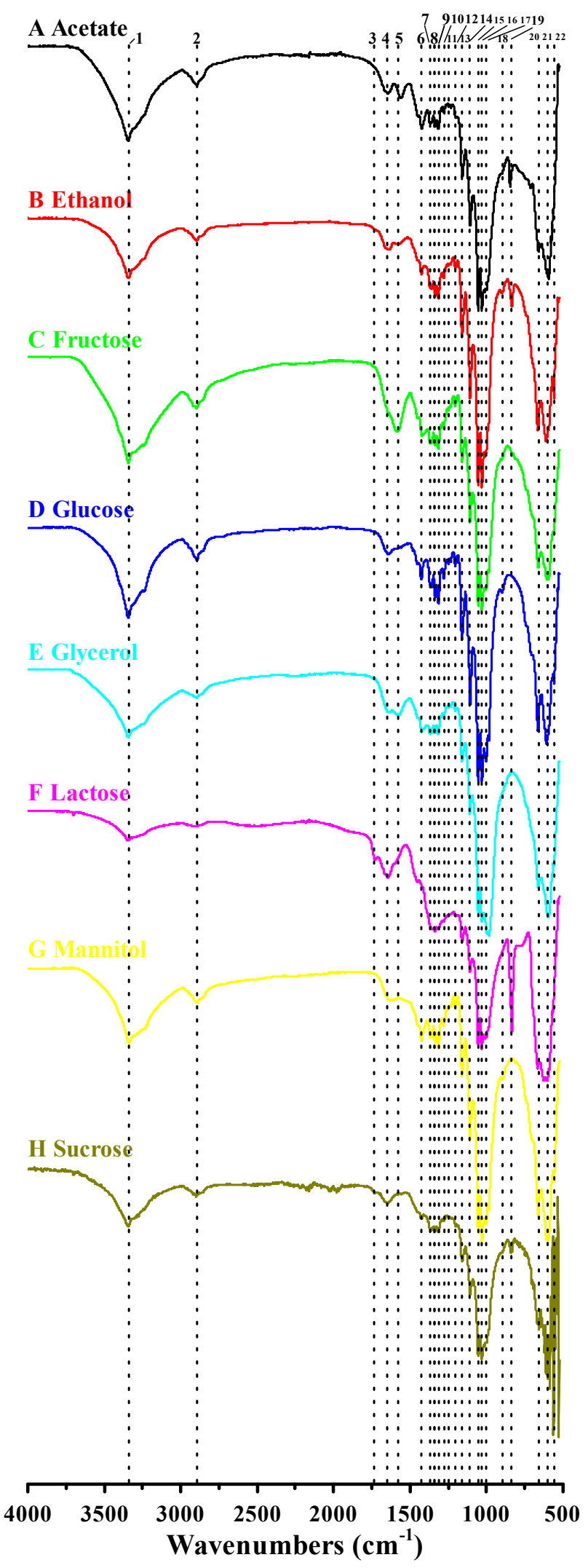

Figure 4. Comparative Fourier transform infrared (FTIR) analysis of the BC produced by Komagataeibacter sp. W1 grown in media spiked with various carbon sources. The analysis was conducted on a Nicolet iS5 in the Attenuated Total Reflectance (ATR) mode with 32 scans per measurement between 400 and $4000 \mathrm{~cm}^{-1}$. The detailed information of peaks 1-22 is given in Table 3 . 
Table 3. Fourier transform infrared (FTIR) analysis of functional groups on BC produced from different carbon sources.

\begin{tabular}{|c|c|c|c|c|c|c|c|c|c|}
\hline \multirow{2}{*}{ Peak Number } & \multicolumn{8}{|c|}{ Wavenumber $\left(\mathrm{cm}^{-1}\right)$} & \multirow{2}{*}{ Functional Groups } \\
\hline & Acetate & Ethanol & Fructose & Glucose & Glycerol & Lactose & Mannitol & Sucrose & \\
\hline 1 & 3344 & 3343 & 3343 & 3343 & 3344 & 3345 & 3341 & 3346 & $\mathrm{O}-\mathrm{H}$ stretching vibration \\
\hline 2 & 2895 & 2896 & 2895 & 2895 & 2895 & 2897 & 2894 & 2899 & $\mathrm{C}-\mathrm{H}$ stretching of $\mathrm{CH}_{2}$ and $\mathrm{CH}_{3}$ groups \\
\hline 3 & $-{ }^{a}$ & - & - & - & - & 1730 & - & 1734 & $\mathrm{UK}^{\mathrm{c}}$ \\
\hline 4 & 1648 & 1645 & - & 1645 & 1645 & 1649 & 1642 & 1647 & $\mathrm{H}-\mathrm{O}-\mathrm{H}$ bending of absorbed water \\
\hline 5 & 1564 & 1573 & 1574 & - & 1574 & - & - & - & UK \\
\hline 6 & 1424 & 1427 & 1423 & 1427 & 1423 & - & 1426 & 1423 & $\mathrm{CH}_{2}$ symmetric bending or $\mathrm{O}-\mathrm{H}$ in plane bending \\
\hline 7 & 1361 & 1360 & 1361 & 1360 & 1361 & 1355 & 1361 & 1361 & $\mathrm{C}-\mathrm{H}$ bending \\
\hline 8 & 1336 & 1335 & 1335 & 1335 & 1336 & 1336 & 1335 & 1335 & $\mathrm{C}-\mathrm{H}$ deformation or $\mathrm{O}-\mathrm{H}$ in-plane bending \\
\hline 9 & 1315 & 1315 & 1315 & 1315 & 1315 & 1315 & 1315 & 1315 & Out-of-plane wagging of the $\mathrm{CH}_{2}$ groups \\
\hline 10 & 1280 & 1281 & 1280 & 1280 & 1281 & $1281^{\mathrm{b}}$ & 1280 & $1280^{\mathrm{b}}$ & $\mathrm{C}-\mathrm{H}$ bending \\
\hline 11 & 1248 & - & 1249 & 1249 & $1249^{\mathrm{b}}$ & - & - & $1249^{\mathrm{b}}$ & UK \\
\hline 12 & $1203^{\mathrm{b}}$ & 1205 & 1205 & 1205 & 1204 & $1203^{\mathrm{b}}$ & 1205 & $1202^{\mathrm{b}}$ & C-H bending \\
\hline 13 & 1160 & 1161 & 1161 & 1161 & 1161 & 1160 & 1160 & 1161 & C-O-C antisymmetric bridge stretching of $1,4-\beta$-D-glucoside \\
\hline 14 & 1108 & 1108 & 1108 & 1108 & 1108 & 1109 & 1108 & 1108 & $\mathrm{C}-\mathrm{C}$ bonds of the monomer units of polysaccharide or $\mathrm{C}-\mathrm{O}$ bending vibration \\
\hline 15 & 1055 & 1055 & 1054 & 1054 & 1055 & 1056 & 1055 & 1054 & \\
\hline 16 & 1031 & 1031 & 1031 & 1031 & 1031 & 1032 & 1030 & 1032 & The bending of $\mathrm{C}-\mathrm{O}-\mathrm{H}$ bond of carbohydrates or $\mathrm{C}-\mathrm{O}-\mathrm{C}$ pyranose ring skeletal vibration \\
\hline 17 & $1003^{\mathrm{b}}$ & $1005^{\mathrm{b}}$ & $1003^{\mathrm{b}}$ & 1004 & 997 & $1002^{\mathrm{b}}$ & 1003 & $1002^{\mathrm{b}}$ & UK \\
\hline 18 & $899^{\mathrm{b}}$ & 899 & - & 899 & - & - & 895 & - & Antisymmetric out-of-phase ring stretching of $\beta$-glucosidic linkages between the glucose units \\
\hline 19 & 847 & 835 & - & - & - & 836 & - & 836 & UK gicon \\
\hline 20 & 660 & 664 & 663 & 664 & 662 & 666 & 663 & 657 & \\
\hline 21 & 600 & 609 & 602 & 609 & 597 & 602 & 601 & 597 & O-H out-of-phase bending vibration \\
\hline 22 & 563 & 559 & 557 & 558 & 563 & 564 & 558 & 562 & \\
\hline
\end{tabular}


As noted previously, BC characterization is often performed by using XRD and ${ }^{13} \mathrm{C}-\mathrm{NMR}$ methods $[46,55,56]$. However, due to the overlap of cellulose $I_{\alpha}$ and $I_{\beta}$ reflections, it is difficult to differentiate the two allomorphs by only determining the XRD peak positions [12]. Molina-Ramírez et al. [2] showed that the FTIR could help distinguish $I_{\alpha}$ allomorph (around 3240 and $750 \mathrm{~cm}^{-1}$ ) from $I_{\beta}$ allomorph (around 3270 and $710 \mathrm{~cm}^{-1}$ ). The $I_{\alpha}$ fractions of BCs produced from fructose, glucose, and sucrose in K. medellinensis were from 0.70 to 0.74 [2], which were higher than A. xylinus 23769 of 0.36-0.43 [23], A. xylinus strains ATCC 10245, IFO 13693, IFO13772, IFO13773, IFO14815, and IFO15237 of 0.38-0.43 [54], and Komagataeibacter sp. W1 of 0.51 for all groups in our study. However, our data were in accordance with the well-known fact that for $I_{\alpha}$ it is as high as about $64 \%$ in BC [57]. We hypothesized that strain W1 possessed the capacity to produce both allomorphs at the same time, and the ability to produce $I_{\alpha}$ and $I_{\beta}$ was stable irrespective of the spiked carbon sources.

\subsection{Insights into the Biochemical Pathways for Carbon Sources Utilization and BC Synthesis}

In micro-organisms, several metabolic pools are involved in BC biosynthesis. One direct pathway to produce $\mathrm{BC}$ is to pre-generate hexose phosphate by the phosphorylation of exogenous hexoses [35]. To this aim, the isomers fructose and glucose are ideal carbon sources for BC production, which was supported by our findings (Figure 1 and Figure S1). As to other carbon sources, transforming to the above two hexoses is the first and important step to produce $B C$ through the pentose cycle and gluconeogenic pathway [58]. In addition to physio-biochemical observation and evaluation of BC synthesis in micro-organisms, it is also important to understand the metabolic network of carbon sources [41]. However, this is scarcely reported in existing studies.

Our previous study obtained the genome information of strain W1 and annotated some associated enzymes in glucose transformation and BC synthesis [3]. To explore how strain W1 utilized other carbon sources and then produced BC, this study also summarized the orfs responsible for various carbon source metabolisms and BC production. As shown in Figure 5 and Table S1, strain W1 had 157 orfs corresponding to various carbon source metabolisms, most of which had been studied in this work except for mannose, glycogen/starch, and trehalose. In fact, besides those orfs responsible for encoding the enzymes involved in direct glucose transformation and cellulose synthesis and regulation, we also found more indirect orfs aiming for these processes (Table S1). In general, strain W1 had 27 orfs associated with alcohol (ethanol) metabolism, being the highest among 11 groups, followed by glucose metabolism of 24 and glycerol metabolism of 22 (Figure 5). This was understandable because strain W1 was an acetic bacterium used for vinegar production (alcohol metabolism) and a typical BC-producer capable of BC production (glucose metabolism) [3]. Unlike normal carbon substrates, glycerol not only can be transformed to glucose, it is also easily degraded and used as a source of energy to enhance the TCA cycle $[23,24,41]$. It was interesting to note that both orfs corresponding to fructose and mannitol metabolism were less than for the others except for trehalose and glycogen/starch (Figure 5). Apparently, the number of orfs did not follow the trend of BC productivities as described previously (Figure 1C), suggesting that carbon source metabolism might also be impacted by other factors such as enzymatic activity, substrate preference, and metabolic fluxes [2,59]. 


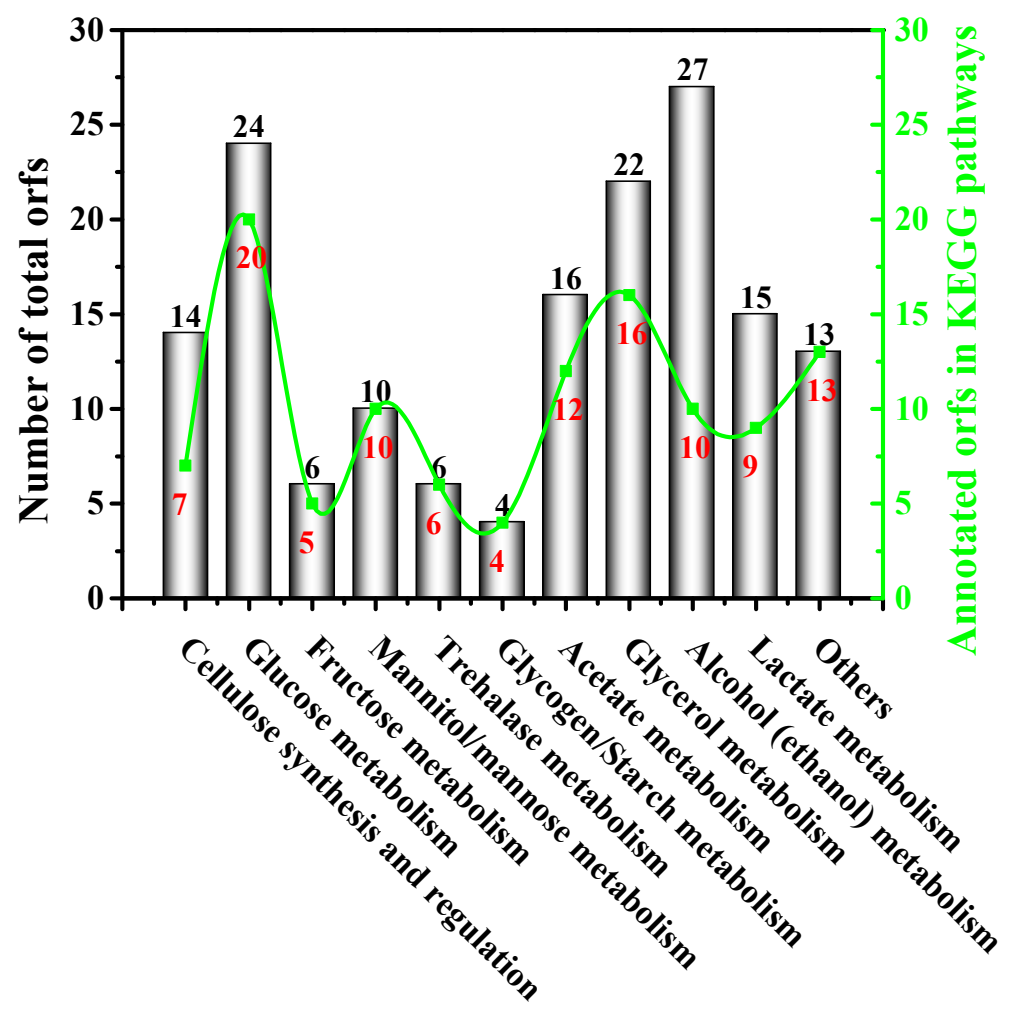

Figure 5. The number of orfs associated with carbon source metabolisms and BC biosynthesis and regulation. The orfs shown here were retrieved from the genes and corresponding protein annotation data. While the numbers on the top of the bars indicate the total number of predicted genes involved in carbon source metabolisms and BC biosynthesis and regulation, the ones below the line indicate the number of the genes that can be annotated to certain Kyoto Encyclopedia of Genes and Genomes (KEGG) pathways. It's worthy to note that the description 'others' indicates the key metabolic intermediates during the transformation between glucose and glycerol or fructose and glycerol. More details can be found in Tables S1 and S2.

To have a full understanding of carbon source metabolism and BC production in strain W1, we further provided an overview of the orfs that could be annotated to certain KEGG pathways (Figure 5; Table S2). Based on the coupling analysis of the orfs-KEGG pathway, the schematic diagram of carbon source metabolism and BC biosynthesis pathways in Komagataeibacter sp. W1 were also provided (Figure 6). As expected, most orfs could be annotated to a certain KEGG pathway (Figure 5), and all corresponding enzymes are given in Table S2 and labeled in Figure 6. Specifically, fructose, mannitol, and glycerol could be enzymatically transformed to glucose, and then produce $\mathrm{BC}$, through the pentose phosphate pathway or gluconeogenesis pathway [59], but lactose and sucrose did not (Figure 6). Although acetate and ethanol were able to generate acetyl coenzyme A (acetyl-CoA) and functioned in the TCA cycle and glycerol transformation, we did not find any possible pathway linking them to glucose or other sugars (Figure 6). Since media glucose was removed before seed solution transfer, it was possible that both acetate and ethanol were not the precursors of glucose and the few BCs observed in our study might be due to the release of cell glucose and subsequent BC production (Figure 1). We also noticed that glycerol, mannitol, and fructose had two pathways (i.e., the pyruvate pathway and glycerate-phosphate pathway) to produce oxaloacetate and enter the TCA cycle [24], thereby enhancing energy generation and carbon sources utilization for BC production (Figures 1 and 6). However, our results were different from Molina-Ramírez et al. [2] in that glucose obtained 86\% higher BC than fructose, again showing that different bacterial strains had different traits for carbon source utilization and $\mathrm{BC}$ production (Table 1). 


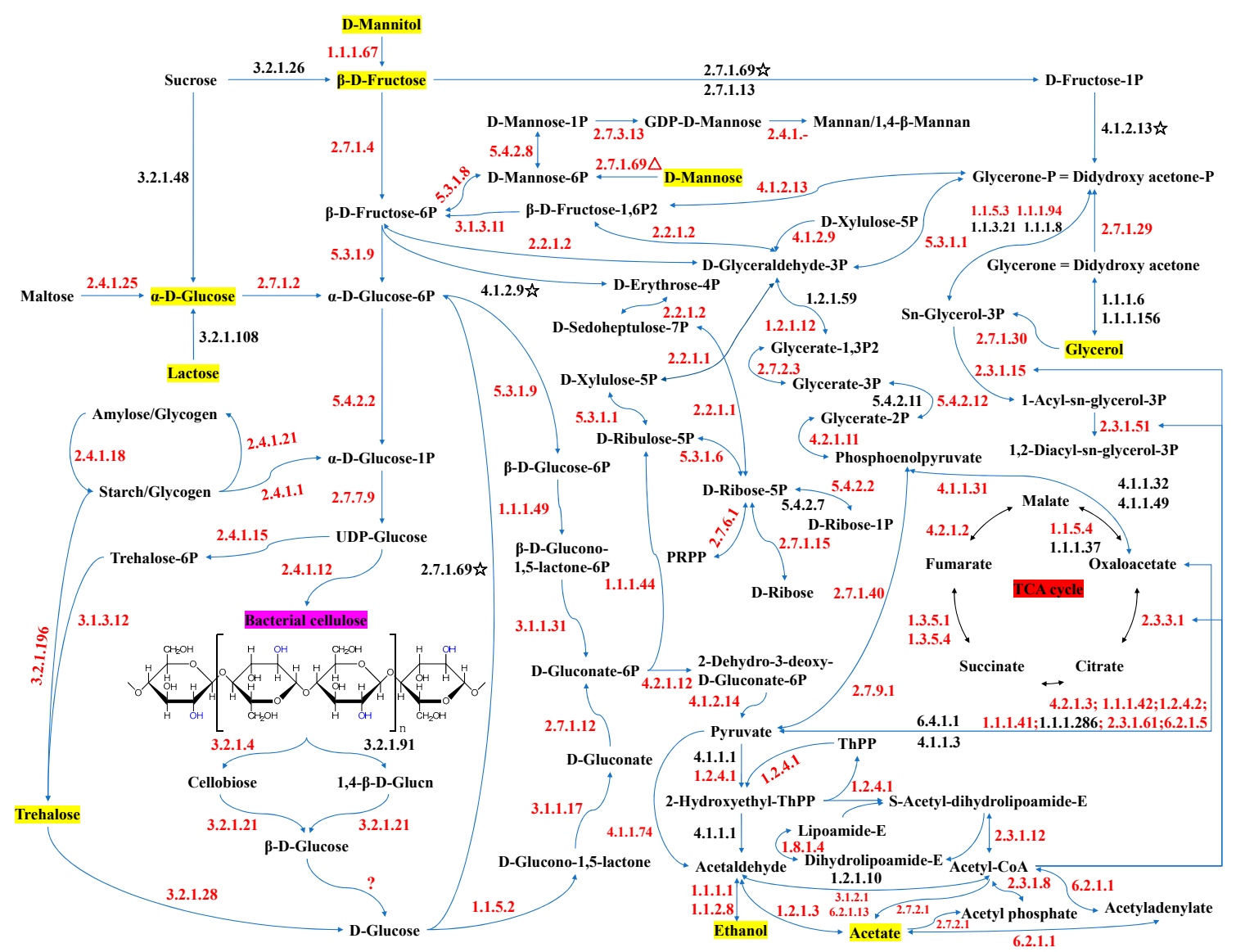

Figure 6. Schematic diagram of carbon metabolism and BC biosynthesis pathways in Komagataeibacter sp. W1. The comprehensive analysis was conducted by incorporating the key metabolic intermediates and associated enzymes responsible for carbon source transformation and $\mathrm{BC}$ biosynthesis in different KEGG pathways. The numbers in the figure are the Enzyme Commission number, while the red and black ones indicate the associated enzymes present and absent respectively in Komagataeibacter sp. W1. The asterisks indicate the enzymes absent in the labeled pathways but present in other pathways in our study, thus it is unknown whether they work in the labeled pathways. The question mark indicating whether the pathway is present, is unclear based on our data and remains for future investigations. More information of the enzymes and the associated genes and pathways (ko numbers) are listed in Table S2. P, phosphate; GDP, guanosine diphosphate; UDP, uridine diphosphate; PRPP, phosphoribosyl pyrophosphate; ThPP, thiamine diphosphate; TCA, tricarboxylic acid cycle; Acetyl-CoA, acetyl coenzyme A.

\section{Conclusions}

In this study, Komagataeibacter sp. W1, which is a typical BC-producer, was subjected to media spiked with various carbon sources including acetate, ethanol, fructose, glucose, lactose, mannitol, and sucrose and the $\mathrm{BC}$ productivity, $\mathrm{BC}$ characteristics and biochemical transformation pathways associated with carbon source transformation and $\mathrm{BC}$ production were investigated. This strain preferred to use fructose, glucose, glycerol, and mannitol for BC production, with the highest $\mathrm{BC}$ yield being $1.529 \mathrm{~g} \mathrm{~L}^{-1}$ on fructose. SEM analysis suggested that the membranes produced from all carbon sources were composed of nanofibrils with an average diameter of $35-50 \mathrm{~nm}$, which is a typical characteristic of BC, consistent with the results from XRD and FTIR analyses. Based on genome annotation and KEGG analysis, all biochemical transformation pathways associated with the utilization of and BC production from fructose, glucose, glycerol, and mannitol were found. Our data 
provided suggestions to further investigations of strain $\mathrm{W} 1$ to produce $\mathrm{BC}$ by using the above carbon sources and gave clues on understanding how this strain produces BC at the metabolic pathway scale.

Supplementary Materials: The following are available online at http:/ /www.mdpi.com/2073-4360/10/9/963/s1, Figure S1: Structures of various carbon sources (A-H) and bacterial cellulose (I), Table S1: Open reading frames and corresponding proteins information based on NCBI non-redundant protein (Nr) and Swissprot annotations, Table S2: Open reading frames and corresponding proteins information based on KEGG pathway annotation.

Author Contributions: Conceptualization, S.-S.W., Y.-H.H. and D.-C.Z.; Data curation, S.-S.W., Y.-H.H. and D.-C.Z.; Funding acquisition, S.-S.W., Y.-H.H. and D.-L.C.; Investigation, S.-S.W., J.-L.C., Y.-X.Y. and X.-X.S.; Methodology, D.-L.C. and M.L.; Supervision, D.-L.C. and M.L.; Writing—original draft, S.-S.W., Y.-H.H., D.-L.C. and M.L.; Writing—review \& editing, S.-S.W., Y.-H.H., J.-L.C., D.-C.Z., Y.-X.Y., X.-X.S., D.-L.C. and M.L. The authors S.-S.W. and Y.-H.H. equally contributed to this work and can be considered co-first authors.

Acknowledgments: This research was funded by the Science and Technology Program of Fujian Province (2017Y0027), the Education Department Fund of Fujian Province (JAT170144), the Key Technology Research and Development Platform of Synthetic Resin Functionalization of Fujian Province (2014H2003) and the Key Research and Development Platform of Advanced Polymer Materials (2016G003), the Special Fund of Quangang Petrochemical Research Institute of Fujian Normal University (2017YJY13) and the Hong-Wu Weng Original Fund of Peking University.

Conflicts of Interest: The authors declare no conflict of interest.

\section{References}

1. Velásquez-Riaño, M.; Bojacá, V. Production of bacterial cellulose from alternative low-cost substrates. Cellulose 2017, 24, 2677-2698. [CrossRef]

2. Molina-Ramírez, C.; Castro, M.; Osorio, M.; Torres-Taborda, M.; Gómez, B.; Zuluaga, R.; Gómez, C.; Gañán, P.; Rojas, O.J.; Castro, C. Effect of different carbon sources on bacterial nanocellulose production and structure using the low $\mathrm{pH}$ resistant strain Komagataeibacter medellinensis. Materials 2017, 10, 639. [CrossRef] [PubMed]

3. Wang, S.-S.; Han, Y.-H.; Ye, Y.-X.; Shi, X.-X.; Xiang, P.; Chen, D.-L.; Li, M. Physicochemical characterization of high-quality bacterial cellulose produced by Komagataeibacter sp. strain W1 and identification of the associated genes in bacterial cellulose production. RSC Adv. 2017, 7, 45145-45155. [CrossRef]

4. Gallegos, A.M.A.; Carrera, S.H.; Parra, R.; Keshavarz, T.; Iqbal, H.M.N. Bacterial cellulose: A sustainable source to develop value-added products-A review. BioResources 2016, 11, 5641-5655. [CrossRef]

5. Klemm, D.; Heublein, B.; Fink, H.-P.; Bohn, A. Cellulose: Fascinating biopolymer and sustainable raw material. Angew. Chem. Int. Ed. 2005, 44, 3358-3393. [CrossRef] [PubMed]

6. Ling, S.; Chen, W.; Fan, Y.; Zheng, K.; Jin, K.; Yu, H.; Buehler, M.J.; Kaplan, D.L. Biopolymer nanofibrils: Structure, modeling, preparation, and applications. Prog. Polym. Sci. 2018, 85, 1-56. [CrossRef]

7. Khosravi-Darani, K.; Koller, M.; Akramzadeh, N.; Mortazavian, A.M. Bacterial nanocellulose: Biosynthesis and medical application. Biointerface Res. Appl. Chem. 2016, 6, 1511-1516.

8. Huang, X.; Zhan, X.; Wen, C.; Xu, F.; Luo, L. Amino-functionalized magnetic bacterial cellulose/activated carbon composite for $\mathrm{Pb}^{2+}$ and methyl orange sorption from aqueous solution. J. Mater. Sci. Technol. 2018, 34, 855-863. [CrossRef]

9. Jin, X.; Xiang, Z.; Liu, Q.; Chen, Y.; Lu, F. Polyethyleneimine-bacterial cellulose bioadsorbent for effective removal of copper and lead ions from aqueous solution. Bioresour. Technol. 2017, 244, 844-849. [CrossRef] [PubMed]

10. Reiniati, I.; Hrymak, A.N.; Margaritis, A. Recent developments in the production and applications of bacterial cellulose fibers and nanocrystals. Crit. Rev. Biotechnol. 2017, 37, 510-524. [CrossRef] [PubMed]

11. Krasteva, P.V.; Bernal-Bayard, J.; Travier, L.; Martin, F.A.; Kaminski, P.-A.; Karimova, G.; Fronzes, R.; Ghigo, J.-M. Insights into the structure and assembly of a bacterial cellulose secretion system. Nat. Commun. 2018, 8, 2065. [CrossRef] [PubMed]

12. Singhsa, P.; Narain, R.; Manuspiya, H. Physical structure variations of bacterial cellulose produced by different Komagataeibacter xylinus strains and carbon sources in static and agitated conditions. Cellulose 2018, 25, 1571-1581. [CrossRef]

13. Mikkelsen, D.; Flanagan, B.M.; Dykes, G.A.; Gidley, M.J. Influence of different carbon sources on bacterial cellulose production by Gluconacetobacter xylinus strain ATCC 53524. J. Appl. Microbiol. 2009, 107, 576-583. [CrossRef] [PubMed] 
14. Keshk, S.M.A.S.; Sameshima, K. Evaluation of different carbon sources for bacterial cellulose production. Afr. J. Biotechnol. 2005, 4, 478-482.

15. Kose, R.; Sunagawa, N.; Yoshida, M.; Tajima, K. One-step production of nanofibrillated bacterial cellulose (NFBC) from waste glycerol using Gluconacetobacter intermedius NEDO-01. Cellulose 2013, 20, 2971-2979. [CrossRef]

16. Çoban, E.; Biyik, H. Effect of various carbon and nitrogen sources on cellulose synthesis by Acetobacter lovaniensis HBB5. Afr. J. Biotechnol. 2011, 10, 5346-5354.

17. Gatenholm, P.; Höglund, K.; Johannesson, S.; Puchades, M.; Brackmann, C.; Enejder, A.; Olsson, L. Effect of Cultivation Conditions on the Structure and Morphological Properties of BNC Biomaterials with a Focus on Vascular Grafts. In Bacterial NanoCellulose-A Sophisticated Multifunctional Material, 1st ed.; Gama, M., Gatenholm, P., Klemm, D., Eds.; CRC Press: Boca Raton, FL, USA, 2013; pp. 20-42.

18. Yunoki, S.; Osada, Y.; Kono, H.; Takai, M. Role of ethanol in improvement of bacterial cellulose production: Analysis using ${ }^{13}$ C-labeled carbon sources. Food Sci. Technol. Res. 2004, 10, 307-313. [CrossRef]

19. Yang, X.-Y.; Huang, C.; Guo, H.-J.; Xiong, L.; Luo, J.; Wang, B.; Chen, X.-F.; Lin, X.-Q.; Chen, X.-D. Beneficial effect of acetic acid on the xylose utilization nd bacterial cellulose production by Gluconacetobacter xylinus. Indian J. Microbiol. 2014, 54, 268-273. [CrossRef] [PubMed]

20. Park, J.K.; Jung, J.Y.; Park, Y.H. Cellulose production by Gluconacetobacter hansenii in a medium containing ethanol. Biotechnol. Lett. 2003, 25, 2055-2059. [CrossRef] [PubMed]

21. Lu, Z.; Zhang, Y.; Chi, Y.; Xu, N.; Yao, W.; Sun, B. Effects of alcohols on bacterial cellulose production by Acetobacter xylinum 186. World J. Microb. Biot. 2011, 27, 2281-2285. [CrossRef]

22. Huang, C.; Yang, X.-Y.; Xiong, L.; Guo, H.-J.; Luo, J.; Wang, B.; Zhang, H.-R.; Lin, X.-Q.; Chen, X.-D. Evaluating the possibility of using acetone-butanol-ethanol (ABE) fermentation wastewater for bacterial cellulose production by Gluconacetobacter xylinus. Lett. Appl. Microbiol. 2015, 60, 491-496. [CrossRef] [PubMed]

23. Kiziltas, E.E.; Kiziltas, A.; Gardner, D.J. Synthesis of bacterial cellulose using hot water extracted wood sugars. Carbohydr. Polym. 2015, 124, 131-138. [CrossRef] [PubMed]

24. Jung, H.-I.; Jeong, J.-H.; Lee, O.-M.; Park, G.-T.; Kim, K.-K.; Park, H.-C.; Lee, S.-M.; Kim, Y.-G.; Son, H.-J. Influence of glycerol on production and structural-physical properties of cellulose from Acetobacter sp. V6 cultured in shake flasks. Bioresour. Technol. 2010, 101, 3602-3608. [CrossRef] [PubMed]

25. Chen, S.-Q.; Mikkelsen, D.; Lopez-Sanchez, P.; Wang, D.; Martinez-Sanz, M.; Gilbert, E.P.; Flanagan, B.M.; Gidley, M.J. Characterisation of bacterial cellulose from diverse Komagataeibacter strains and their application to construct plant cell wall analogues. Cellulose 2017, 24, 1211-1226. [CrossRef]

26. Chen, S.-Q.; Lopez-Sanchez, P.; Wang, D.; Mikkelsen, D.; Gidley, M.J. Mechanical properties of bacterial cellulose synthesised by diverse strains of the genus Komagataeibacter. Food Hydrocolloids 2018, 81, 87-95. [CrossRef]

27. Hestrin, S.; Schramm, M. Synthesis of cellulose by Acetobacter xylinum. 2. Preparation of freeze-dried cells capable of polymerizing glucose to cellulose. Biochem. J. 1954, 58, 345-352. [CrossRef] [PubMed]

28. Mohammadkazemi, F.; Azin, M.; Ashori, A. Production of bacterial cellulose using different carbon sources and culture media. Carbohydr. Polym. 2015, 117, 518-523. [CrossRef] [PubMed]

29. Segal, L.; Creely, J.J.; Martin, A.E., Jr.; Conrad, C.M. An empirical method for estimating the degree of crystallinity of native cellulose using the X-ray diffractometer. Text. Res. J. 1959, 29, 786-794. [CrossRef]

30. Yamamoto, H.; Horii, F.; Hirai, A. In situ crystallization of bacterial cellulose II. Influences of different polymeric additives on the formation of celluloses $I_{\alpha}$ and $I_{\beta}$ at the early stage of incubation. Cellulose 1996, 3, 229-242. [CrossRef]

31. Saxena, I.M.; Malcolm Brown, R.J. Biosynthesis of Bacterial Cellulose. In Bacterial NanoCellulose-A Sophisticated Multifunctional Material, 1st ed.; Gama, M., Gatenholm, P., Klemm, D., Eds.; CRC Press: Boca Raton, FL, USA, 2013; pp. 1-18.

32. Augimeri, R.V.; Varley, A.J.; Strap, J.L. Establishing a role for bacterial cellulose in environmental interactions: Lessons learned from diverse biofilm-producing Proteobacteria. Front. Microbiol. 2015, 6, 1282. [CrossRef] [PubMed]

33. Castro, C.; Zuluaga, R.; Putaux, J.-L.; Caro, G.; Mondragon, I.; Gañán, P. Structural characterization of bacterial cellulose produced by Gluconacetobacter swingsii sp. from Colombian agroindustrial wastes. Carbohydr. Polym. 2011, 84, 96-102. [CrossRef]

34. Gullo, M.; China, S.L.; Falcone, P.M.; Giudici, P. Biotechnological production of cellulose by acetic acid bacteria: Current state and perspectives. Appl. Microbiol. Biotechnol. 2018, 102, 6885-6898. [CrossRef] [PubMed] 
35. Ross, P.; Mayer, R.; Benziman, M. Cellulose biosynthesis and function in bacteria. Microbiol. Mol. Biol. Rev. 1991, 55, 35-58.

36. Ramana, K.V.; Tomar, A.; Singh, L. Effect of various carbon and nitrogen sources on cellulose synthesis by Acetobacter xylinum. World J. Microb. Biotechnol. 2000, 16, 245-248. [CrossRef]

37. Ago, M.; Yamane, C.; Hattori, M.; Ono, H.; Okajima, K. Characterization of morphology and physical strength for bacterial cellulose produced by an Enterobacter sp. Sen-i Gakkaishi 2006, 62, 42-46. [CrossRef]

38. Tanskul, S.; Amornthatre, K.; Jaturonlak, N. A new cellulose-producing bacterium, Rhodococcus sp. MI 2: Screening and optimization of culture conditions. Carbohydr. Polym. 2013, 92, 421-428. [CrossRef] [PubMed]

39. Hassan, E.A.; Abdelhady, H.M.; El-Salam, S.S.A.; Abdullah, S.M. The characterization of bacterial cellulose produced by Acetobacter xylinum and Komgataeibacter saccharovorans under optimized fermentation conditions. Brit. Microbiol. Res. J. 2015, 9, 1-13. [CrossRef]

40. Kojima, Y.; Seto, A.; Tonouchi, N.; Tsuchida, T.; Yoshinaga, F. High rate production in static culture of bacterial cellulose from sucrose by a newly isolated Acetobacter strain. Biosci. Biotech. Biochem. 1997, 61, 1585-1586. [CrossRef]

41. Tabaii, M.J.; Emtiazi, G. Comparison of bacterial cellulose production among different strains and fermented media. Appl. Food Biotechnol. 2016, 3, 35-41.

42. Ishihara, M.; Matsunaga, M.; Hayashi, N.; Tišler, V. Utilization of d-xylose as carbon source for production of bacterial cellulose. Enzyme Microb. Technol. 2002, 31, 986-991. [CrossRef]

43. Recouvreux, D.O.S.; Carminatti, C.A.; Pitlovanciv, A.K.; Rambo, C.R.; Porto, L.M.; Antônio, R.V. Cellulose biosynthesis by the beta-proteobacterium, Chromobacterium violaceum. Curr. Microbiol. 2008, 57, 469-476. [CrossRef] [PubMed]

44. Hungund, B.S.; Gupta, S.G. Production of bacterial cellulose from Enterobacter amnigenus GH-1 isolated from rotten apple. World J. Microb. Biotechnol. 2010, 26, 1823-1828. [CrossRef]

45. Trovatti, E.; Serafim, L.S.; Freire, C.S.R.; Silvestre, A.J.D.; Neto, C.P. Gluconacetobacter sacchari: An efficient bacterial cellulose cell-factory. Carbohydr. Polym. 2011, 86, 1417-1420. [CrossRef]

46. Thorat, M.; Dastager, S. High yield production of cellulose by a Komagataeibacter rhaeticus PG2 strain isolated from pomegranate as a new host. RSC Adv. 2018, 8, 29797-29805. [CrossRef]

47. Volova, T.G.; Prudnikova, S.V.; Sukovatyi, A.G.; Shishatskaya, E.I. Production and properties of bacterial cellulose by the strain Komagataeibacter xylinus B-12068. Appl. Microbiol. Biotechnol. 2018, 102, 7417-7428. [CrossRef] [PubMed]

48. Tan, L.; Ren, L.; Cao, Y.; Chen, X.; Tang, X. Bacterial cellulose synthesis in Kombucha by Gluconacetobacter sp and Saccharomyces sp. Adv. Mater. Res. 2012, 554-556, 1000-1003. [CrossRef]

49. Amano, Y.; Ito, F.; Kanda, T. Novel cellulose producing system by microorganisms such as Acetobacter sp. J. Biol. Macromol. 2005, 5, 3-10.

50. Yamanaka, S.; Watanabe, K.; Kitamura, N.; Iguchi, M.; Mitsuhashi, S.; Nishi, Y.; Uryu, M. The structure and mechanical properties of sheets prepared from bacterial cellulose. J. Mater. Sci. 1989, 24, 3141-3145. [CrossRef]

51. Bi, J.C.; Liu, S.X.; Li, C.F.; Li, J.; Liu, L.X.; Deng, J.; Yang, Y.C. Morphology and structure characterization of bacterial celluloses produced by different strains in agitated culture. J. Appl. Microbiol. 2014, 117, 1305-1311. [CrossRef] [PubMed]

52. French, A.D. Idealized powder diffraction patterns for cellulose polymorphs. Cellulose 2014, 21, 885-896. [CrossRef]

53. Tokoh, C.; Takabe, K.; Fujita, M.; Saiki, H. Cellulose synthesized by Acetobacter xylinum in the presence of acetyl glucomannan. Cellulose 1998, 5, 249-261. [CrossRef]

54. Keshk, S.; Sameshima, K. The utilization of sugar cane molasses with/without the presence of lignosulfonate for the production of bacterial cellulose. Appl. Microbiol. Biotechnol. 2006, 72, 291-296. [CrossRef] [PubMed]

55. Meza-Contreras, J.C.; Manriquez-Gonzalez, R.; Gutiérrez-Ortega, J.A.; Gonzalez-Garcia, Y. XRD and solid state ${ }^{13} \mathrm{C}-\mathrm{NMR}$ evaluation of the crystallinity enhancement of ${ }^{13} \mathrm{C}$-labeled bacterial cellulose biosynthesized by Komagataeibacter xylinus under different stimuli: A comparative strategy of analyses. Carbohydr. Res. 2018, 461, 51-59. [CrossRef] [PubMed]

56. Yamamoto, H.; Horn, F. In situ crystallization of bacterial cellulose I. Influences of polymeric additives, stirring and temperature on the formation celluloses $I_{\alpha}$ and $I_{\beta}$ as revealed by cross polarization/magic angle spinning (CP/MAS) ${ }^{13} \mathrm{C}$ NMR spectroscopy. Cellulose 1994, 1, 57-66. [CrossRef] 
57. Yamamoto, H.; Horii, F. CP/MAS ${ }^{13} \mathrm{C}$ NMR analysis of the crystal transformation induced for Valonia cellulose by annealing at high temperatures. Macromolecules 1993, 26, 1313-1317. [CrossRef]

58. Colvin, J.R.; Leppard, G.G. The biosynthesis of cellulose by Acetobacter xylinum and Acetobacter acetigenus. Can. J. Microbiol. 1977, 23, 701-709. [CrossRef] [PubMed]

59. Zhong, C.; Zhang, G.-C.; Liu, M.; Zheng, X.-T.; Han, P.-P.; Jia, S.-R. Metabolic flux analysis of Gluconacetobacter xylinus for bacterial cellulose production. Appl. Microbiol. Biotechnol. 2013, 97, 6189-6199. [CrossRef] [PubMed]

(C) 2018 by the authors. Licensee MDPI, Basel, Switzerland. This article is an open access article distributed under the terms and conditions of the Creative Commons Attribution (CC BY) license (http:/ / creativecommons.org/licenses/by/4.0/). 